\title{
Prevalence of weathering nodules of the ear in patients treated at the state civil servant's hospital of São Paulo, Brazil ${ }^{*}$
}

\author{
Prevalência de pápulas climáticas das orelhas nos pacientes atendidos no \\ hospital do servidor público estadual de São Paulo, Brasil
}

\author{
Juliana Nunes Maciel Cilento ${ }^{1}$
}

Neusa Yuriko Sakai Valente ${ }^{2}$

\begin{abstract}
BACKGROUND: Weathering nodules of the ear are pale yellow, asymptomatic lesions which predominate on the helices of the ears. Although their pathogenesis remains unknown, there is an association with chronic exposure to ultraviolet radiation, age and thermal injuries. Few studies have been conducted to date, and these involved a very small number of patients.

OвјестіvE: Study the prevalence of weathering nodules of the ear in patients treated in the Dermatology Service of the State Civil Servant's Hospital of São Paulo, and evaluate their probable relationship with sun exposure, age and phototypes I and II.

MeтноDs: Four hundred patients older than 20 years of age were examined between July 2008 and December 2008. A questionnaire evaluating age, sex, place of birth, origin, occupation and history of sun exposure was applied. All patients were examined and evaluated for the presence of lesions by only one person.

REsults: The data showed that 155 (38.8\%) patients had a lesion in at least one of the ears. The Chi-Square Test was used for the comparative analysis between the groups of patients with and without lesions. In the group of patients with lesions, $29 \%$ were 70 to 79 years old, $78.1 \%$ had a history of sun exposure and $45.1 \%$ belonged to FITZPATRICK skin phototypes I and II ( $\mathrm{p}<0.05 \%)$.

Conclusion: The findings suggest relevant prevalence, probable association with chronic sun exposure, advanced age and phototypes I and II.
\end{abstract}

Keywords: Ear; Ear cartilage; Metaplasia; Skin aging

Resumo: FundamENTOS: Pápulas climáticas das orelhas são lesões assintomáticas de coloração amarelo-pálida que predominam na hélice das orelhas. Sua patogênese permanece desconhecida, no entanto é descrita a associação com exposição crônica à radiação ultravioleta, idade e injúrias térmicas. Poucos estudos foram realizados até o momento e os mesmos envolveram número muito reduzido de pacientes.

OBJETıvo: Estudar a prevalência de pápulas climáticas das orelhas nos doentes atendidos no Serviço de Dermatologia no Hospital Servidor Estadual de São Paulo e avaliar a provável relação com exposição solar, idade e tipo de pele.

MÉTODOs: Foram examinados 400 pacientes com idade superior a vinte anos no período compreendido entre os meses de julho de 2008 a dezembro de 2008. Foi aplicado questionário que avaliou idade, sexo, naturalidade, procedência, profissão e história de exposição solar Todos os sujeitos da pesquisa foram examinados por um único observador e avaliados quanto à presença de lesão.

RESultados: Os dados revelaram que 155 (38,8\%) pacientes apresentavam lesão em pelo menos uma das orelhas. Foi utilizado o teste do Qui-Quadrado para análise comparativa entre o grupo de pacientes com e sem lesão. No grupo de pacientes com lesão $29 \%$ tinham idade entre 70 e 79 anos, 78,1\% tinham história de exposição solar e 45,1\% pertenciam ao fototipo I e II da classificação de FITZPATRICK $(\mathrm{p}<0,05 \%)$.

CONCLUSÃO: Os achados sugerem prevalência relevante, provável associação com exposição solar crônica, idade avançada e com o fototipo I e II.

Palavras-chave: Cartilagem da orelha; Envelhecimento da pele; Metaplasia; Orelha

Received on 25.10.2011

Approved by the Advisory Board and accepted for publication on 11.04.2012.

* Work performed at the Hospital do Servidor Público Estadual (HSPE) - São Paulo (SP), Brazil.

Financial Support: None.

Conflict of Interests: None.

1 Dermatologist by the Brazilian Society of Dermatology. Post-graduate candidate in Health Sciences at the Hospital do Servidor Público Estadual (HSPE) - São Paulo (SP), Brazil.

PhD by the Dermatology Department of the Universidade de São Paulo (USP) - Physician responsible by the Dermatopatholgy Sector and Preceptor at the Dermatology Service of the Hospital do Servidor Público Estadual (HSPE) - São Paulo (SP), Brazil. 


\section{INTRODUCTION}

The international references in the medical literature on the clinicopathological entity initially described by Kavanagh and colleagues in 1996 as "weathering nodules of the ear" are scarce. In this study we propose the denomination, in Portuguese, "pápulas climáticas da orelba" for this entity, due to the elementary lesion observed clinically and maintaining the adjective of the original publication.

The lesions are described as pale yellow, asymptomatic nodules or papules, of approximately $2-3 \mathrm{~mm}$ of diameter, with a consistency similar to cartilage when palpated. They predominate on the antihelix of the ear, but are also observed on the helix, and typically occur in white men living in tropical regions. Multiple nodules may be present, forming a chain and acquiring the aspect of an indented helix. Mostly, these are findings of the physical examination, and seldom consist of the patient's main complaint. ${ }^{1,2}$

The histopathological exam shows solar elastosis, dilated vessels in the superficial dermis and absence of inflammatory cells. Some authors suggest the presence of a spiculum of fibrous tissue with cartilaginous metaplasia. ${ }^{1}$

Unlike the chondrodermatitis nodularis helicis, there is no inflammation or ulceration. ${ }^{3,4}$ Other possible differential diagnoses are: elastotic nodules of the ears, rheumatoid nodules and calcinosis cutis. However, the weathering papules take on individual characteristics that differentiate them from such entities. ${ }^{5,6,7}$

Although their pathogenesis remains unknown, there is an association with chronic exposure to ultraviolet radiation, age and thermal injuries. ${ }^{1,2,6}$ The probable relationship with actinic damage requires a detailed evaluation of the subject, because its prevention demands protection against the sun of this region, by both physical (caps and hats) and chemical means (sunscreen).

The study of the prevalence of weathering nodules of the ear is justified by the scarcity of studies on this subject, not only regarding the prevalence of the entity, but also the predominant age group, triggering factors, clinical presentation and differential diagnosis.

\section{Objectives}

Study the prevalence of weathering nodules of the ear in patients treated in the Dermatology Service of the State Civil Servant's Hospital of São Paulo, and evaluate the probable relationship with sun exposure, age and phototype.

\section{PATIENTS AND METHODS}

Four hundred patients older than 20 years of age were consecutively examined between July 2008 and December 2008 in the Outpatient Clinic of the
Dermatology Service of the State Civil Servant's Hospital in São Paulo. We conducted a cross-sectional observational study (or prevalence study), with a descriptive-analytic approach, based on convenience sampling. A questionnaire evaluating age, gender, place of birth, origin, occupation and history of sun exposure was applied by only one examiner.

All patients enrolled in the study were examined and evaluated by only one person for the presence of lesions and were asked about the existence of symptoms. The cases showing the most characteristic and/or exuberant lesions, or giving rise to doubts with regard to the diagnosis were photographed and submitted to a biopsy, in accordance with an informed consent form signed by the patient.

Therefore, besides the descriptive analysis, comparisons between patients with and without lesions were performed for this work.

The Chi-Square Test was used to check if the distribution of the several variables was similar in the different groups (with or without lesion). The significance level for all tests was set at 5\%. Therefore, the differences between the groups were considered when p-value was less than 0.05 (p-value $<0.05$ ).

\section{Ethical aspects}

The work was submitted to the Scientific Ethics Committee of the State Civil Servant's Hospital of São Paulo for evaluation. All standards set forth in the Resolution 196/96 of the National Council of Health of the Brazilian Ministry of Health, which regulates the clinical research, were met.

All patients who met the enrollment criteria received the informed consent form, which they read, understood and signed before the data collection.

The patients were free to withdraw their consent at anytime during the study.

\section{Exclusion criteria}

Patients younger than 20 years old were excluded.

\section{RESULTS}

Qualitative variables were presented as absolute frequencies (n) and relative frequencies (\%).

Of the 400 patients studied, 155 (38.8\%) had a lesion on at least one of the ears (Table 1).

The Chi-Square Test was used to check if the distribution of the several variables was similar in the different groups (with or without lesion). The significance level for all tests was set at 5\%. Therefore, the differences between the groups were considered when p-value was less than 0.05 (p-value $<0.05$ ).

For the crossings in which there was evidence of statistical association $(p<0.05)$, the residual analy- 
Table 1: Presence of lesion (right and/or left ear)

$(n=400)$

\begin{tabular}{lll}
\hline & $\mathbf{N}$ & $\mathbf{\%}$ \\
No & 245 & 61.3 \\
Yes & 155 & 38.8 \\
\hline Total & $\mathbf{4 0 0}$ & $\mathbf{1 0 0 . 0}$
\end{tabular}

sis was used to identify the pairs of categories corresponding to a value above the expected, that is, which categories differ between the groups. A value of the standardized residual (Zres) above 1.96 indicates statistical significance in the cell (specific category for a certain group) with a significance level of $5 \%$. When the residual was above 1.96 , the residue value was highlighted.

The prevalence was $38.8 \%$ with $95 \%$ CI $(35,1: 42,5 \%)$. The results showed that $29 \%$ of patients with lesion were in the age group of 70-79 years old, and $11.6 \%$ were older than 80 years.

Regarding sun exposure, $78.1 \%$ of patients with lesion had a history of sun exposure $(p<0.001)$, $41.3 \%$ of which was occupational $(\mathrm{p}<0.001)$; $36.8 \%$ reported greater association with occasional, leisurerelated exposure $(\mathrm{p}<0.034)$.

Regarding skin type, $39.9 \%$ of patients with lesion belonged to phototype II, and $38.6 \%$ belonged to phototype III $(\mathrm{p}<0.001)$.

There was no significant difference with respect to sex between the groups of patients with and without lesion (Table 2). lesions.

No patient reported symptoms associated with

\section{DISCUSSION}

Weathering nodules of the ear consist of asymptomatic lesions involving the helices and antihelices of the ears, affecting mainly white men and patients with chronic actinic damage. ${ }^{1,2}$

Papules, nodules or plates, in general bilateral, yellowish, translucid, soft and painless can be observed at the clinical examination (Figure 1). ${ }^{1,5}$

The histopathological exam shows elastosis, vasodilation and absence of inflammatory cells and degeneration of the elastic fibers. ${ }^{1,5}$ The hypothesis of cartilaginous metaplasia may be related with the actinic damage, considering that prolonged sun exposure could stimulate this phenomenon. Another possible influence is the localization on the helices and antihelices of the ears, regions with a thin layer of subcutaneous tissue and poor vascularization. ${ }^{1,3}$

There were 400 patients in the study, 155 (38.8\%) of which had a lesion on at least one of the

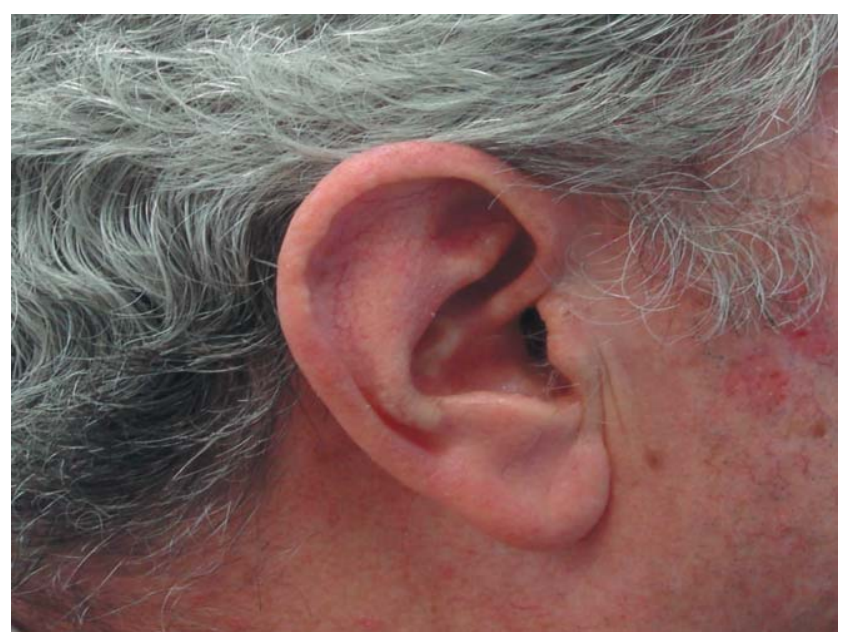

Figure 1: Translucent papules in the helix of the ear

ears. The prevalence of weathering papules in the patients studied shows that this entity may be underdiagnosed, since the lack of symptoms, non-exuberant clinical findings and the fact that the ears are seldom examined may have an influence on the absence of diagnosis.

The results above indicate that there was an association statistically significant for all variables, except sex, evidencing that there is a higher percentage of patients aged 39 years old and younger among those without lesion, and a higher percentage of patients aged between 70 and 79 years in the group with lesions.

Regarding sun exposure, the data showed that there is a higher percentage of patients without a history of sun exposure among those without lesion, and a higher percentage of patients with any history of sun exposure among those with lesion; a higher percentage of patients with a history of occupational sun exposure among those with lesion; and a higher percentage of patients with a history of leisure-related sun exposure among those with lesion.

Regarding skin type, a higher percentage of patients with phototype I and II among those with lesion evident and a higher percentage of patients with phototype $\mathrm{V}$ and VI among those without lesion were evident.

The results found match the literature reports with regard to the probable association with chronic sun exposure and advanced age. ${ }^{1,2,8,9}$ The predominance in patients with Fitzpatrick I and II indicates an association with race.

Some works suggest a male predominance, and this is usually attributed to the fact that many women use their hair covering the ears, but we did not find a statistical significance for this variable. ${ }^{10}$ 
TABLE 2: Statistical analysis of variables

\begin{tabular}{|c|c|c|c|c|c|c|}
\hline \multirow[t]{2}{*}{$(n=400)$} & \multicolumn{5}{|c|}{$\begin{array}{l}\text { Presence of lesion } \\
\text { (right and/or left ear) }\end{array}$} & \multirow[t]{2}{*}{ p-value } \\
\hline & $\begin{array}{l}\text { No } \\
\text { n }\end{array}$ & $\begin{array}{l}\text { Yes } \\
\%\end{array}$ & $\mathbf{n}$ & $\%$ & & \\
\hline \multirow[t]{6}{*}{ AGE } & $20-39$ & 39 & $\begin{array}{l}\mathbf{1 5 . 9 \%} \\
(3.3)\end{array}$ & 8 & $5.2 \%$ & \multirow[t]{6}{*}{0.005} \\
\hline & $40-49$ & 31 & $12.7 \%$ & 20 & $12.9 \%$ & \\
\hline & $50-59$ & 54 & $22.0 \%$ & 30 & $19.4 \%$ & \\
\hline & $60-69$ & 56 & $22.9 \%$ & 34 & $21.9 \%$ & \\
\hline & $70-79$ & 41 & $16.7 \%$ & 45 & $\begin{array}{l}29.0 \% \\
(2.9)\end{array}$ & \\
\hline & $\geq 80$ & 24 & $9.8 \%$ & 18 & $11.6 \%$ & \\
\hline \multirow[t]{2}{*}{ SEX } & Male & 96 & $39.2 \%$ & 74 & $47.7 \%$ & \multirow[t]{2}{*}{0.092} \\
\hline & Female & 149 & $60.8 \%$ & 81 & $52.3 \%$ & \\
\hline History of sun exposure (yes/no) & No & 126 & $51.9 \%$ & 34 & $21.9 \%$ & $<0.001$ \\
\hline Yes & 117 & $48.1 \%$ & 121 & $78.1 \%$ & & \\
\hline \multirow[t]{2}{*}{ History of sun exposure (occupational) } & No & 190 & $78.2 \%$ & 91 & $58.7 \%$ & \multirow[t]{2}{*}{$<0.001$} \\
\hline & Yes & 53 & $21.8 \%$ & 64 & $41.3 \%$ & \\
\hline \multirow{2}{*}{ History of sun exposure (leisure) } & No & 178 & $73.3 \%$ & 98 & $63.2 \%$ & \multirow{2}{*}{0.034} \\
\hline & Yes & 65 & $26.7 \%$ & 57 & $36.8 \%$ & \\
\hline \multirow[t]{8}{*}{ FITZPATRICK - Skin types } & I & 2 & $0.8 \%$ & 8 & $5.2 \%$ & \multirow{8}{*}{$<0.001$} \\
\hline & II & 69 & $28.4 \%$ & 61 & $\begin{array}{l}(2.7) \\
39.9 \%\end{array}$ & \\
\hline & & & & & $(2.4)$ & \\
\hline & III & 101 & $41.6 \%$ & 59 & $38.6 \%$ & \\
\hline & IV & 39 & $16.0 \%$ & 20 & $13.1 \%$ & \\
\hline & $\mathrm{V}$ & 24 & $9.9 \%$ & & & \\
\hline & & & (2.5) & 5 & $3.3 \%$ & \\
\hline & VI & 8 & $\begin{array}{l}3.3 \% \\
(2.3)\end{array}$ & & & \\
\hline
\end{tabular}

No patient reported any symptoms associated with the lesions, but some lesions with mild phlogistic signs were found (Figure 2).

Some patients with evident actinic damage had exuberant lesions, grouped, of a larger diameter and in a greater number. No patient had a history of intense exposure to cold weather.

There are studies that suggest a possible association with chondrodermatitis nodularis. ${ }^{1}$ The chondrodermatitis nodularis has a different appearance, and is characterized by painful, erythematous nodules, with ulceration or a crust at the center of the lesion, ${ }^{3}$ different, therefore, from the weathering papules. In our view, one cannot exclude that the weathering papules inflame due to mechanical trauma caused mainly by the pillow, during sleep, and

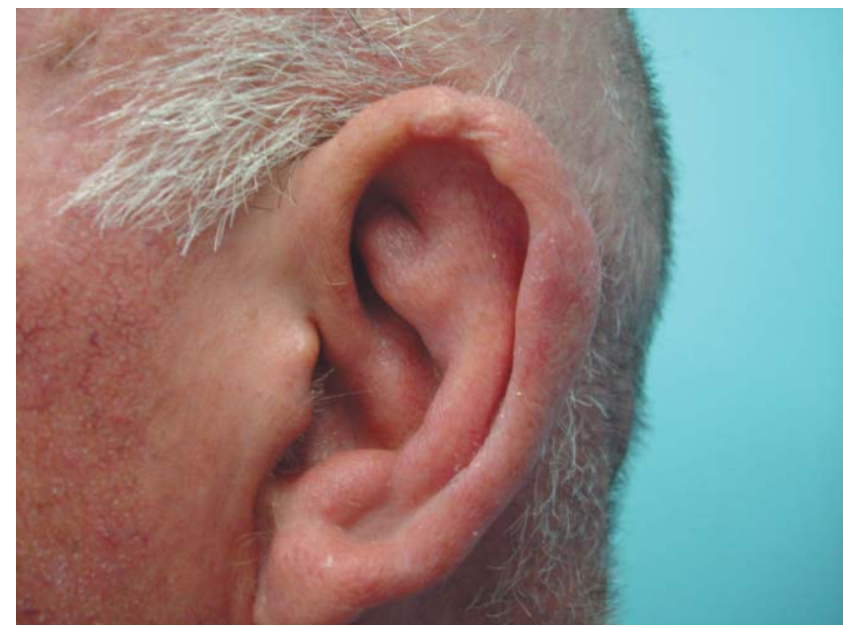

FIGURE 2: Erythematous papula in the helix of the ear 
then present themselves as chondrodermatitis nodularis. The case presented by Devani \& Barankin 2007 appears to demonstrate this. ${ }^{11}$ In our work, physical examination revealed some mildly erythematous lesions.

As already mentioned, weathering papules are painless, pale yellow lesions, sometimes with a slight scaling. The predominance of this entity in older patients is also different from the age group of the chondrodermatitis nodularis, where there is a greater prevalence of younger individuals, and is more frequent on the helices of the ears. ${ }^{3,4}$

Histologically, in chondrodermatitis nodularis, hyperplasia of the epidermis, altered collagen, proliferation of granulation tissue and rich inflammatory infiltrate are found. ${ }^{3,4}$

Another differential diagnosis of the weathering papules are the elastotic nodules, which are also asymptomatic, probably related to chronic actinic damage, but their histopathological characteristics differentiate them from the weathering papules by the deposition of elastotic tissue. , $^{5,6,12}$

Other clinical differential diagnoses should also be considered, such as calcinosis cutis, rheumatoid nodules, xanthomas. However, the weathering nodules of the ears take on clinical and histopathological characteristics that differentiate them from such entities. ${ }^{5,6,7}$

\section{CONCLUSION}

The few studies conducted to date on the weathering nodules of the ears are usually just case reports, but the significant prevalence found in this study, which involved a greater number of patients, indicates that such entity should be understood by the dermatologist, and may be the subject of interest for new studies as well.

\section{REFERENCES}

1. Kavanagh GM, Bradfiel JWB, Collins CMP, Kennedy CTC, Kennedy CTC. Weathering nodules of the ear: a clinical pathologic study. Br J Dermatol. 1996;135:550-4.

2. Kennedy CTC. The External Ear. In: Burns T, Breathnac S, Cox N, Griffiths C editors. Rook,s Textbook of dermatology. vol 4. 7th ed. Oxford: Blackwell publishing; 2004 p.6511-13.

3. Bard J. Chondrodermatitis nodularis chronica helices. Dermatologica. 1981;163:376-84

4. Cribier B, Scrivener $Y$, Peltre B. Neural hyperplasia in chondrodermatitis nodularis chronica helicis. J Am Acad Dermatol. 2006;55:844-8.

5. Carter VH, Costantine VS, Poole WL. Elastotic nodules of the antihelix. Arch Dermatol. 1969;100:282-5.

6. Weedon D. Elastotic nodules of the ear. J Cutan Pathol. 1981;8:429-33.

7. Kennedy $\mathrm{C}$. Weathering nodules are not the same as elastotic nodules. J Am Acad Dermatol. 2005;52:925-6.

8. Jellinek N. Iotafotaderma. J Am Acad Dermatol. 2003;49:1108.

9. Requena L, Aguilar A, Sanches-Yus E. Elastotic nodules of the ears. Cutis. $1989 ; 44: 452-4$
10. Amichai B, Shiri J. Weathering nodules of the ear in a young woman. Br J Dermatol. 1997;137:659.

11. Denavi A, Barakin B, Question: Can you identify this condition? Can Fam Physician. 2007; 53:821.

12. Assis TL, Sampaio SB, Carneiro SJC. Senescência cutânea: Nódulos elastóticos das orelhas. An Bras Dermatol. 1973;48:187-91.

MAILING ADDRESS:

Juliana Nunes Maciel Cilento

Manaíra, Maria Eunice Fernandes, 130

58038480 João Pessoa PB Brazil

E-mail:junmaciel@yaboo.com.br

How to cite this article: Cilento JNM, Valente NYS. Prevalence of weathering nodules of the ear in patients treated at the state civil servant's hospital of São Paulo, Brazil. An Bras Dermatol. 2013;88(1):64-8. 